\title{
Correction to: Neisseria lactamica Y92-1009 complete genome sequence
}

\author{
Anish K. Pandey ${ }^{1 *}$, David W. Cleary', Jay R. Laver ${ }^{1}$, Martin C. J. Maiden², Xavier Didelot ${ }^{3}$, Andrew Gorringe ${ }^{4}$ \\ and Robert C. Read ${ }^{1 *}$
}

\section{Correction}

After publication of the original article [1] it was identified that an incorrect version of the manuscript has been published. This was caused by a technical error which led to a discrepancy between the editorially-accepted version of the manuscript, and the published version.

A list of Corrections is included below:

1) The following abbreviations have been corrected throughout the article:

Nla changed to $N$. lactamica

Nme changed to N. meningitides

N.go changed to N. gonorrhoeae

$N c i$ changed to $N$. cinerea

2) Table 1: 'Term' and 'Evidence code' columns of the first 7 rows have been updated to the following:

\begin{tabular}{ll}
\hline Domain Bacteria & TAS $[37]$ \\
Phylum Proteobacteria & TAS $[38]$ \\
Class Betaproteobacteria & TAS $[39,40]$ \\
Order Neisseriales & TAS $[39,41]$ \\
Family - Neisseriaceae & TAS $[42]$ \\
Genus Neisseria & TAS $[42]$ \\
Species Neisseria lactamica & TAS $[42,43]$
\end{tabular}

\footnotetext{
* Correspondence: anishkumarpandey89@gmail.com; r.c.read@soton.ac.uk ${ }^{1}$ Faculty of Medicine, Southampton NIHR Biomedical Research Centre and Institute for Life Sciences, University of Southampton, Southampton, UK Full list of author information is available at the end of the article

3) Table 2: Missing/blank term for MIGS 13 has been changed to read "Strain is not publicly available".

4) 2nd paragraph under heading "Insights from the genome sequence": Sentence containing “... approximately a third (33.5\%) of all open reading frames (ORFs) in this genome..." has been shortened to "approximately a third (33.5\%) of all ORFs in this genome..."

5) 3rd paragraph under heading "Insights from the genome sequence": Bracketed abbreviation '(DUS)' has been removed.

6) 3rd paragraph under heading "Insights from the genome sequence": Bracketed abbreviation '(CREEs)' has been removed

7) Bracketed link for PHAST '(http:// phast.wishartlad.com/index.html)' changed to reference 35 .

8) Reference 14 initially missing from article, has now been added and correctly referenced

9) Reference 33 was removed, as it was a duplicate of reference 30 .

10) References $36-40$ removed, and replaced with updated reference list (36-46):

36. Field D, Garrity G, Gray T, Morrison N, Selengut J, Sterk $\mathrm{P}$, et al. The minimum information about a genome sequence (MIGS) specification. Nat Biotechnol. 2008;26:541-7.

37. Woese CR, Kandler O, Wheelis ML. Towards a natural system of organisms: proposal for the domains Archaea, Bacteria, and Eucarya. Proc Natl Acad Sci. 1990;87:4576-9. https://doi.org/10.1073/pnas.87.12.4576.

38. Garrity GM, Holt JG. The Road Map to the Manual. In: Bergey's Manual ${ }^{\circ}$ of Systematic Bacteriology. 2001. p. 119-66. https://doi.org/10.1007/978-0-38721609-6_15.

39. Euzeby. J. List of new names and new combinations previously effectively, but not validly, published. Int J Syst Evol Microbiol. 2006;56:1-6. 
40. Garrity GM, Bell JA, Lilburn T. Class II. Betaproteobacteria class. Nov. In: Bergey's Manual ${ }^{\circ}$ of Systematic Bacteriology. 2005. p. 575-922. https:// doi.org/10.1007/0-387-29298-5_2.

41. Tønjum T. Neisseriales ord. Nov. In: Bergey's Manual of Systematics of Archaea and Bacteria. John Wiley \& Sons, Ltd.; 2015. https://doi.org/10.1002/ 9781118960608 .obm00079.

42. SKERMAN VBD, McGOWAN V, SNEATH PHA. Approved Lists of Bacterial Names. Int J Syst Evol Microbiol. 1980;30:225-420.

43. Hollis DG, Wiggins GL, Weaver RE. Neisseria lactamicus sp. n., a lactose-fermenting species resembling Neisseria meningitidis. Appl Microbiol. 1969;17:71-7.

44. Aho EL, Keating a M, McGillivray SM. A comparative analysis of pilin genes from pathogenic and nonpathogenic Neisseria species. Microb Pathog. 2000;28:81-8.

45. Lennette, Edwin H. Manual of Clinical Microbiology. 4th edition. Washington DC: American Society for Microbiology; 1985.

46. Neisseria MLST website. https://pubmlst.org/ neisseria/. Accessed 2 Feb 2017.

The Publisher apologises for this error.

\section{Author details}

${ }^{1}$ Faculty of Medicine, Southampton NIHR Biomedical Research Centre and Institute for Life Sciences, University of Southampton, Southampton, UK.

${ }^{2}$ Department of Zoology, University of Oxford, South Parks Road, Oxford, UK. ${ }^{3}$ Department of Infectious Disease Epidemiology, Imperial College London, London, UK. ${ }^{4}$ Public Health England, Porton Down, UK.

Published online: 16 February 2018

\section{Reference}

1. Pandey AK, Cleary DW, Laver JR, Maiden MCJ, Didelot X, Gorringe A, Read RC. Neisseria lactamica Y92-1009 complete genome sequence. Stand Genomic Sci. 2017;12:41. https://doi.org/10.1186/s40793-017-0250-6. 